\title{
Survivorship and clinical outcomes of proximal femoral replacement in non- neoplastic primary and revision total hip arthroplasty: a systematic review
}

\author{
Fabio Mancino ${ }^{1,2,3^{*}} \mathbb{D}$, Vincenzo Di Matteo ${ }^{1,2}$, Fabrizio Mocini ${ }^{1,2}$, Giorgio Cacciola ${ }^{4}$, Giuseppe Malerba ${ }^{1}$,
}

Carlo Perisano ${ }^{1}$ and Ivan De Martino ${ }^{1}$

\begin{abstract}
Background: Several studies have evaluated the survivorship and clinical outcomes of proximal femoral replacement (PFR) in complex primary and revision total hip arthroplasty with severe proximal femoral bone loss; however, there remains no consensus on the overall performance of this implant. We therefore performed a systematic review of the literature in order to examine survivorship and complication rates of PFR usage.

Methods: A systematic review of the literature according to the Preferred Reporting Items for Systematic Reviews and Meta-Analyses guidelines was performed. A comprehensive search of PubMed, MEDLINE, EMBASE, and the Cochrane Database of Systematic Reviews was conducted for English articles using various combinations of keywords.

Results: In all, 18 articles met the inclusion criteria. A total of 578 PFR were implanted. The all-cause reoperation-free survivorship was $76.6 \%$. The overall complication rate was $27.2 \%$. Dislocation was the most common complication observed and the most frequent reason for reoperation with an incidence of 12.8 and $7.6 \%$, respectively. Infection after PFR had an incidence of $7.6 \%$ and a reoperation rate of $6.4 \%$. The reoperation rate for aseptic loosening of the implant was 5.9\%. Overall, patients had improved outcomes as documented by postoperative hip scores.
\end{abstract}

Conclusion: PFR usage have a relatively high complication rate, however, it remains an efficacious treatment option in elderly patients with osteoporotic bone affected by severe proximal femoral bone loss. Modular designs have shown reduced dislocations rate and higher survivorship free from dislocation. However, PFR should only be used as salvage procedure when no other reconstruction options are available.

Keywords: Proximal femoral replacement, Proximal femoral arthroplasty, Femoral revision, Femoral bone loss, Bone defect, Femoral reconstruction, Total hip arthroplasty, Revision hip arthroplasty

*Correspondence: fabio_mancino@yahoo.com

${ }^{3}$ Adult Reconstruction and Joint Replacement Service, Division of Orthopaedics and Traumatology, Department of Aging, Neurological, Orthopaedic and Head-Neck studies, Fondazione Policlinico, Universitario Agostino Gemelli IRCCS, Largo Agostino Gemelli 8, 00168 Roma, RM, Italy

Full list of author information is available at the end of the article

\section{Background}

Total hip arthroplasty (THA) is one of the most successful surgical procedures of the past 50 years. However, despite the overall success, revision THA remains a costly and challenging procedure to manage for the surgeon, especially in case of severe femoral and/or acetabular bone loss [1]. original author(s) and the source, provide a link to the Creative Commons licence, and indicate if changes were made. The images or other third party material in this article are included in the article's Creative Commons licence, unless indicated otherwise in a credit line to the material. If material is not included in the article's Creative Commons licence and your intended use is not permitted by statutory regulation or exceeds the permitted use, you will need to obtain permission directly from the copyright holder. To view a copy of this licence, visit http://creativecommons.org/licenses/by/4.0/. The Creative Commons Public Domain Dedication waiver (http://creativeco mmons.org/publicdomain/zero/1.0/) applies to the data made available in this article, unless otherwise stated in a credit line to the data. 
In the setting of femoral revision arthroplasty, significant bone loss continues to be problematic for healthcare professionals, potentially threatening the primary fixation and durability of the reconstruction. Reduced bone stock can be associated with septic and aseptic failure, periprosthetic fracture, osteoporotic fracture in the elderly with severe comminution or failed fracture fixation, and multiple revisions [2-7]. In case of severe proximal femoral bone loss multiple treatment options have been described in the literature, including structural allograft-prosthesis composite, impaction allografting, long revision stems, resection arthroplasty, and proximal femoral replacement (PFR) [3, 4, 8]. Proximal femoral replacement, also known as "megaprosthesis", is a wellestablished limb salvage procedure for reconstruction of bone defects after the oncological resections of malignant bone neoplasms [9] and the encouraging outcomes have broadened the indications to the treatment of severe bone loss in non-oncologic conditions [10,11].

PFR allows a faster recovery especially in elderly patients, and it avoids the disadvantages of bone grafting such as resorption, graft integration, and diseases transmissions $[12,13]$. However, it is associated with an increased risk of infection and instability, secondary to the difficult healing of the abductor mechanism [14].

Multiple studies have described the outcomes of PFR in oncologic patients $[9,10]$, however, only few have described PFR usage in non-oncologic severe femoral bone loss associated with periprosthetic fracture, septic and aseptic revisions, or failed osteosynthesis. We therefore performed a systematic review of the literature in order to examine survivorship and complication rates of PFRs. Specifically, we aimed to examine (1) what is the survivorship from reoperation when PFRs are used? (2) what complications are most common in PFRs? (3) what is the cumulative incidence of hip dislocation with PFRs? (4) do PFRs provide adequate implant survivorship in line with alternative treatment methods in the management of severe femoral bone loss? and (5) what are their clinical outcomes?

\section{Methods}

\section{Search strategy}

This search was conducted in accordance with the Preferred Reporting Items for Systematic Reviews and Meta-Analyses guidelines [15]. The US National Library of Medicine (PubMed/MEDLINE), EMBASE, and the Cochrane Database of Systematic Reviews were queried for publications utilizing various combinations of the search terms "proximal femur replacement," "proximal femur megaprosthesis," "hip megaprosthesis," "proximal femur arthroplasty," "non-oncologic," "bone loss," "femoral reconstruction," "bone defect," "femoral revision," in combination with the Boolean operators (AND, OR, *) since inception of database to January 2021. No limit was set with regard to the year of publication. Two authors (F.Ma. and V.D.M.) independently conducted all the searches and screened the titles and abstracts to identify relevant studies. Differences were resolved by consulting a third senior reviewer (I.D.M.). Only abstracts that evaluated the clinical outcomes and survivorship of nononcologic patients with PFR following primary or revision THA were reviewed. If the title and abstract of each study contained insufficient information, the full manuscript was reviewed. An additional search was conducted by screening the references list of each selected article.

\section{Inclusion and exclusion criteria}

Inclusion criteria were any original study in which a PFR was used in primary or revision THA in non-oncologic patients. Postoperative complications, clinical outcomes using validated patient reported scales and implant survivorship where reported. Exclusion criteria were case reports, surgical technique reports, review articles, expert opinions, letters to editors, biomechanical reports, instructional course lectures, studies on animals, cadaver or in vitro investigations, book chapters, abstracts from scientific meetings, unpublished reports, studies with less than 5 hips, studies with a mean follow-up less than 1 year, studies using the same database of patients, studies reporting the use of PFR in oncologic patients, and studies written in non-English language. If a duplicate population was noticed, the study with the longer mean follow-up was included to avoid including the same patients twice.

\section{Data extraction and collection}

Two independent reviewers (F.Ma. and V.D.M.) separately examined all the identified studies and extracted data. During initial review of the data, the following information was collected for each study: title, first author, year of publication, study design, number of patients, patients died and lost at follow-up, age of patients, length of follow-up, indication for index surgery, PFR implant used, complication types, reoperations for any reason, implant loosening, dislocations, deep infections, nerve injuries, and patient-reported outcomes. The level of evidence analysis was determined using the Oxford Centre for Evidence-Based Medicine Levels of Evidence [16]. The methodological quality of each study and the different types of detected bias were assessed independently by each reviewer with the use of Modified Coleman Methodology Score (Fig. 1). The Modified Coleman Methodology score ranges from 0 to 100, with a higher score reflecting higher quality. Final score was categorized as excellent (85-100 points), good (70-84 points), fair (55-69 


\section{Part 1: One score for each of the sections:}

1. Number of patients:

$\begin{array}{ll}\text { a. } & <30 \\ \text { b. } & 30-50 \\ \text { c. } & 51-10 \\ \text { d. } & >100\end{array}$

2. Mean follow-up

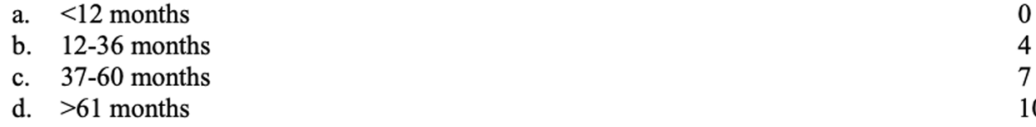

3. Surgical approach

a. Different approaches and outcome not reported separately 0

b. Different approaches and outcome reported separately 7

$\begin{array}{ll}\text { c. Single approach } & 10\end{array}$

4. Type of study

a. Retrospective cohort study 0

b. Prospective cohort study 10

c. Randomized controlled trial 15

5. Description of diagnosis

a. Described without percentage specified

b. Described with percentage specified 5

6. Description of surgical technique

a. Not stated/unclear - Inadequate

b. Only stated - Fair

c. Stated with details - Adequate

7. Description of postoperative rehabilitation

a. Described

b. Not described

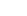

Part 2: Scores can be assigned for each option of every section

1. Outcome criteria

a. Outcome measures clearly specified 2

b. Timing of outcome measures clear 2

c. Outcome measures with reported reliability 3

$\begin{array}{ll}\text { d. General health measure included } & 3\end{array}$

2. Outcome assessment

a. Participants recruited 5

b. Investigator independent of surgeon 4

$\begin{array}{ll}\text { c. Written assessment } & 3 \\ \text { d. Assessment completed by patients } & 3\end{array}$

3. Description of participants selection process

a. Selection criteria reported and unbiased $\quad 5$

b. Recruitment rate reported $(>90 \%) \quad 5$

c. Recruitment rate reported $(<90 \%)$

Fig. 1 Modified Coleman Methodology Score

points), and poor ( $<55$ points). Selective reporting bias was not included in this analysis. Implant failure was defined by need for revision or resection of femoral and/ or acetabular component.

Categorical variables were presented as frequency and percentages. Continuous variables were presented as means. A $P$-value $<0.05$ was considered statistically significant.

\section{Results}

\section{Study selection}

The search query resulted in 2473 abstracts that were then examined to determine if they met the inclusion criteria related to the outcome of PFR for primary and revision THA in non-oncologic patients (Fig. 2). Following elimination of duplicate articles, predetermined inclusion and exclusion criteria were applied. In total, 18 articles met the inclusion criteria and were included in the final analysis [3, 4, 17-32] (Table 1). Consensus on which articles would be analyzed in the present study was achieved by discussion between the reviewers based on the predetermined inclusion and exclusion criteria described above. 


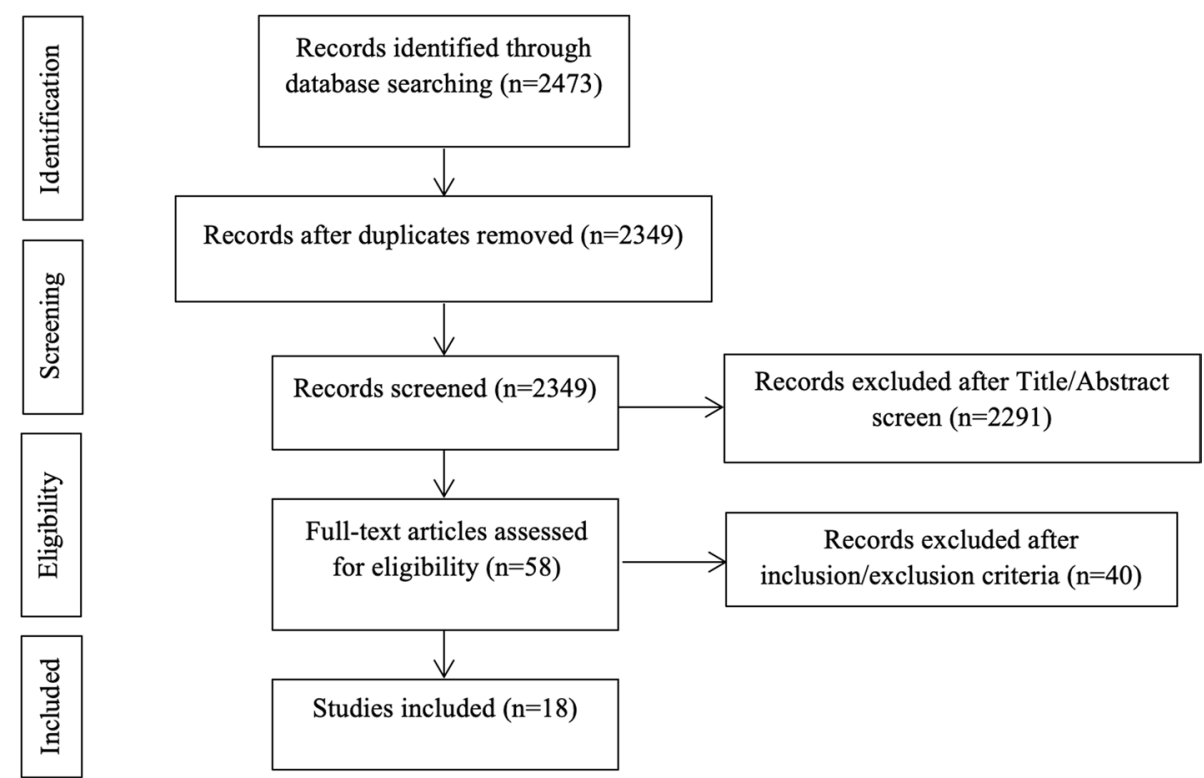

Fig. 2 Flow chart of study selection according to PRISMA guidelines for reporting systematic reviews and meta-analyses

\section{Quality assessment}

The quality of the studies was variable, with the average modified Coleman methodology score of the included studies of 42 points (fair, range 33-50 points), showing that the quality of the studies was low. A meta-analysis was not undertaken due to the general poor quality of the studies. (Table 1)

\section{Demographic data}

A total of 626 patients and 632 hips were initially included in this analysis. After excluding 54 hips (8.5\%) due to missing data or loss to follow-up, 578 hips with a mean age of 70 years (range, 59-79 years) at the time of surgery were included for the final analysis. The mean follow-up was 4.3 years (range, 1.3-11 years) (Table 1).

\section{Indication for PFR}

All eighteen studies specified the indication, at time of surgery, for use of the PFR, however three cases were not clearly specified $(0.5 \%)$ [3, 4, 17-32]. Among the studies where details were reported (629 hips), PFRs were most commonly used in revision THA for the treatment of periprosthetic fractures (187 hips, 29.7\%), followed by 2 -stage revisions with severe bone loss for PJI (184 hips, 29.3\%), and aseptic loosening (AL) of previously implanted THA (163 hips, 25.9\%). PFRs were used as primary implant in case of comminuted fractures in elderly patients in $10.3 \%$ of the cases (65 hips).
Other indications including osteosynthesis failure, and non-union were reported in $4.8 \%$ of the cases (30 hips). Additional information is further outlined in Table 2.

Eleven studies (418 of 578 hips, 70.9\%) reported the average number of operations before the PFR was performed $[3,4,18,19,23,25,28-32]$, the mean number of procedures was 3.0 (range, 0-22). Type of fixation and implant characteristics are outlined in Table 2.

\section{Reoperations}

The all-cause reoperation-free survivorship after PFR implantation was $76.6 \%$ (445 of 578 hips). The overall reoperation rate was $23.4 \%$ (135 of 578 hips) at mean follow-up of 4.3 years (range, 1.3-11 years) (Table 3 ). Dislocation and infection were the most common reasons for reoperation with an incidence of $7.6 \%$ (44 of 578 hips) and $6.4 \%$ (37 of 578 hips), respectively. The reoperation rate for aseptic loosening of the implant was 5.9\% (34 of 579 hips). Reoperation rate due to other complication including periprosthetic fracture and hematoma was $3.1 \%$ (19 of 578). Among those, periprosthetic fracture was the most frequent complication requiring surgery in 12 hips (2.1\%).

\section{Complications}

All 18 studies included complications rates [3, 4, 17-32]. The overall complication rate was $27.2 \%$ (157 of 578 hips). The most common complication reported was dislocation in $12.8 \%$ of the cases ( 74 of 578 hips), followed by 
Table 1 Study characteristics and patiens demographics

\begin{tabular}{|c|c|c|c|c|c|c|c|}
\hline Author (year) & Study Design, LoE & No. Of Patients & $\begin{array}{l}\text { No. Of Hips } \\
\text { Initial/Final }\end{array}$ & Male/Female & Age (range) & $\begin{array}{l}\text { Mean Follow-up } \\
\text { (years) }\end{array}$ & MCS \\
\hline Malkani et al. [17] & Retrospective, IV & 49 & $50 / 50$ & $18 / 31$ & $60.6(27-82)$ & 11.1 & 42 \\
\hline Haentjens et al. [18] & Retrospective, IV & 19 & $19 / 19$ & $6 / 13$ & $78(63-87)$ & 5 & 39 \\
\hline Parvizi et al. [3] & Retrospective, IV & 48 & $48 / 48$ & $16 / 32$ & $73.8(42-97)$ & 3 & 46 \\
\hline Shih et al. [19] & Retrospective, IV & 12 & $13 / 12$ & $9 / 3$ & $59(25-75)$ & 5.7 & 46 \\
\hline Schoenfeld et al. [20] & $\begin{array}{l}\text { Retrospective compara- } \\
\text { tive, III }\end{array}$ & 21 & $22 / 19$ & $10 / 11$ & $76(62-90)$ & 3.4 & 33 \\
\hline Bertani et al. [21] & Retrospective, IV & 10 & $10 / 8$ & N/A & $65(48-82)$ & $3.7-5.4$ & 41 \\
\hline Gebert et al. [22] & Retrospective, IV & 45 & $45 / 45$ & $24 / 21$ & $62(31-81)$ & 3.2 & 43 \\
\hline Sewell et al. [23] & Retrospective, IV & 15 & $15 / 14$ & $8 / 7$ & $67(34-85)$ & 5 & 50 \\
\hline Al Taki et al. [4] & $\begin{array}{l}\text { Retrospective compara- } \\
\text { tive, III }\end{array}$ & 63 & $63 / 36$ & $25 / 38$ & $73(23-94)$ & 3.2 & 46 \\
\hline McLean et al. [24] & Retrospective, IV & 20 & $20 / 20$ & $7 / 13$ & $72(36-91)$ & 4 & 41 \\
\hline Dean et al. [25] & Retrospective, IV & 8 & $8 / 8$ & $4 / 4$ & $67.5(50-79)$ & 1.5 & 39 \\
\hline Colman et al. [26] & Retrospective, IV & 21 & $21 / 21$ & N/A & 75 & 1.25 & 36 \\
\hline Lundh et al. [27] & Retrospective, IV & 5 & 5 & $4 / 1$ & $77(25-91)$ & 4 & 44 \\
\hline $\begin{array}{l}\text { Grammatopoulos et al. } \\
\text { [28] }\end{array}$ & Retrospective, IV & 79 & $80 / 60$ & $28 / 52$ & $69(28-93)$ & 5 & 39 \\
\hline Viste et al. [29] & Retrospective, IV & 44 & $44 / 44$ & $13 / 31$ & $79(53-97)$ & 6 & 47 \\
\hline Fenelon et al. [30] & Retrospective, IV & 78 & $79 / 79$ & $29 / 49$ & $78.3(66-90)$ & 2.6 & 40 \\
\hline De Martino et al. [31] & Retrospective, IV & 40 & $41 / 41$ & $14 / 26$ & $64(29-90)$ & 5 & 45 \\
\hline Dieckmann et al. [32] & Retrospective, IV & 49 & $49 / 49$ & $13 / 36$ & $71(37-85)$ & 4.3 & 44 \\
\hline Total & - & 626 & $632 / 578$ & $228 / 368$ & $70(59-79)$ & $4.3(1.3-11.1)$ & $42(33-5$ \\
\hline
\end{tabular}

LoE Level of Evidence, N/A Not Available, MCS Modified Coleman Score

infection in 7.6\% (44 of 578 hips), implant aseptic loosening in $5.9 \%$ (34 of 578 hips), and periprosthetic fracture in $2.1 \%$ (12 of 529 hips). Other complications including nerve injuries, hematoma, wound complications, and deep vein thrombosis (DVT) were reported in 5.0\% (29 of 578 hips). Further information is outlined in Table 3.

\section{Dislocation}

Dislocation after PFR insertion was the most frequent post-operative complication observed. The overall prevalence of dislocation was $12.8 \%$ (74 of 578 hips) (Table 3). In case of dislocation, conservative treatment with closed reduction was performed in 40.5\% (30 of 74 dislocations), and reoperation was required for $59.5 \% \%$ of all dislocations (44 of 74 dislocations) (Table 3). Among those, revision or resection arthroplasty were performed in $81.8 \%$ (36 hips). Open reduction was performed in 6 hips (13.6\%) [28], and 2 hips were treated with advancement and reattachment of the greater trochanter and by a firm closure of the fascia lata [18].

\section{Aseptic loosening, infection, and other complications}

The incidence of implant aseptic loosening for either femoral stem or cup was $5.9 \%$ (34 of 578 hips). All cases of aseptic loosening reported required further reoperation.
Among those, revision of the acetabular component was performed in $47.0 \%$ of the cases (16 of 34 loose implants), revision of both components was performed in $20.6 \%$ (7 of 34 hips), revision of the femoral component in $23.5 \%$ (8 of 34 hips), and resection arthroplasty in $8.8 \%$ (3 of 34 hips). The overall reoperation rate due to aseptic loosening of the implant was $5.9 \%$ (34 of 578 hips).

The overall incidence of infection was $7.6 \%$ (44 of 578 hips), of those, further reoperation was required in $84.0 \%$ of the cases ( 37 hips), whilst $15.9 \%$ of the cases ( 7 hips) were treated conservatively with suppressive antibiotic therapy. Of the infected hips that required surgery, revision or resection arthroplasty was performed in 23 cases (of 37 hips, 62.2\%), whilst debridement, antibiotics, and implant retention (DAIR) was performed in 14 cases (of 37 hips, 37.9\%) (Table 3). The overall reoperation rate due to infection was $6.4 \%$ (37 of 578 hips).

Other complications were reported in 41 cases (of 578, $7.1 \%)$. Among those, surgical treatment was required in $46.3 \%$ of the cases ( 19 of 41 complications), and periprosthetic fracture was the most frequent complication that required subsequent surgery (12 hips, $2.1 \%)$. In case of periprosthetic fracture, revision of the implant was reported in $75 \%$ of the cases (9 out of 12 hips), and osteosynthesis in $25 \%$ (3 hips). Complications that did not 
Table 2 Indications for surgery, type of PRF, and method of fixation

\begin{tabular}{|c|c|c|c|c|c|c|c|c|}
\hline Author (year) & $\begin{array}{l}\text { Type of } \\
\text { implant }\end{array}$ & Fixation & $\begin{array}{l}\text { No. of } \\
\text { previous } \\
\text { surgery } \\
\text { (range) }\end{array}$ & $\begin{array}{l}\text { Primary Fx } \\
\text { (rate) }\end{array}$ & $\begin{array}{l}\text { Periprosthetic } \\
\text { Fx (range) }\end{array}$ & AL (rate) & PJI (rate) & Other \\
\hline $\begin{array}{l}\text { Malkani et al. } \\
{[17]}\end{array}$ & Monobloc & N/A & N/A & $15(30 \%)$ & $3(6 \%)$ & $26(52 \%)$ & $0(0 \%)$ & $\begin{array}{l}6(12 \%)[5 \\
\text { Girdlestone, } 1 \\
\text { arthrodesis] }\end{array}$ \\
\hline $\begin{array}{l}\text { Haentjens et al. } \\
{[18]}\end{array}$ & $\begin{array}{l}\text { (Protek A.G., } \\
\text { Berne, CH) }\end{array}$ & Cemented & $(1-6)$ & $0(0 \%)$ & $0(0 \%)$ & $19(100 \%)$ & $0(0 \%)$ & $0(0 \%)$ \\
\hline Parvizi et al. [3] & $\begin{array}{l}\text { MRS (Stryker } \\
\text { Orthopaedics, } \\
\text { Mahwah, NJ, } \\
\text { US) }\end{array}$ & Cemented & $2.7(0-8)$ & $1(2 \%)$ & $20(42 \%)$ & $13(27 \%)$ & $13(27 \%)$ & $0(0 \%)$ \\
\hline Shih et al. [19] & $\begin{array}{l}\text { Custom-made } \\
\text { (United Ustar } \\
\text { System, Taipei, } \\
\text { Taiwan) }\end{array}$ & Cemented & $6.5(3-22)$ & $0(0 \%)$ & $3(23 \%)$ & $3(23 \%)$ & $9(70 \%)$ & $0(0 \%)$ \\
\hline $\begin{array}{l}\text { Schoenfeld } \\
\text { et al.[20] }\end{array}$ & $\begin{array}{l}\text { Modular PFR } \\
\text { (Howmedica, } \\
\text { Allendale, NJ; } \\
\text { Biomet, War- } \\
\text { saw, IN, US) }\end{array}$ & Cemented & N/A & $21(100 \%)$ & $0(0 \%)$ & $0(0 \%)$ & $0(0 \%)$ & $0(0 \%)$ \\
\hline $\begin{array}{l}\text { Bertani et al. } \\
\text { [21] }\end{array}$ & $\begin{array}{l}\text { JVC-IX (Wright } \\
\text { Medical } \\
\text { Technology } \\
\text { Inc., Arlington, } \\
\text { TN, US) }\end{array}$ & Cemented & N/A & $2(20 \%)$ & $0(0 \%)$ & $8(80 \%)$ & $0(0 \%)$ & $0(0 \%)$ \\
\hline $\begin{array}{l}\text { Gebert et al. } \\
\text { [22] }\end{array}$ & $\begin{array}{l}\text { MUTARS } \\
\text { (Implantcast } \\
\text { GmbH, Buxte- } \\
\text { hude, DE) }\end{array}$ & $\begin{array}{l}\text { Cemented (3), } \\
\text { Cementless } \\
(42)\end{array}$ & N/A & $0(0 \%)$ & $9(20 \%)$ & 19 (42\%) & $16(36 \%)$ & $0(0 \%)$ \\
\hline Sewell et al. [23] & $\begin{array}{l}\text { METS (Stan- } \\
\text { more Implants } \\
\text { worldwide Ltd, } \\
\text { Stanmore, UK) }\end{array}$ & $\begin{array}{l}\text { Cemented (2), } \\
\text { Cementless } \\
(13)\end{array}$ & $2.8(1-4)$ & $0(0 \%)$ & $2(13 \%)$ & $3(20 \%)$ & $9(60 \%)$ & $\begin{array}{l}1(7 \%) \text { [Painful } \\
\text { excision arthro- } \\
\text { plasty] }\end{array}$ \\
\hline Al Taki et al. [4] & $\begin{array}{l}\text { MRS (Stryker } \\
\text { Orthopaedics, } \\
\text { Mahwah, NJ, } \\
\text { US) }\end{array}$ & $\begin{array}{l}\text { Cemented (33), } \\
\text { Cementless (3) }\end{array}$ & $2(1-5)$ & $0(0 \%)$ & 27 (43\%) & 27 (43\%) & $7(13 \%)$ & $\begin{array}{l}2 \text { (3\%) [Instability } \\
+ \text { bone loss] }\end{array}$ \\
\hline $\begin{array}{l}\text { McLean et al. } \\
\text { [24] }\end{array}$ & $\begin{array}{l}\text { GMRS (Stryker } \\
\text { Inc., Mahwah, } \\
\text { NJ, US) }\end{array}$ & Cemented & N/A & $4(20 \%)$ & $9(45 \%)$ & $0(0 \%)$ & $7(35 \%)$ & $0(0 \%)$ \\
\hline Dean et al. [25] & $\begin{array}{l}\text { METS (Stan- } \\
\text { more Implants } \\
\text { worldwide Ltd, } \\
\text { Stanmore, UK) }\end{array}$ & N/A & $3.1(1-11)$ & $8(100 \%)$ & $0(0 \%)$ & $0(0 \%)$ & $0(0 \%)$ & $0(0 \%)$ \\
\hline $\begin{array}{l}\text { Colman et al. } \\
\text { [26] }\end{array}$ & $\begin{array}{l}\text { Modular Endo- } \\
\text { prosthetic PFR }\end{array}$ & N/A & N/A & $0(0 \%)$ & $21(100 \%)$ & $0(0 \%)$ & $0(0 \%)$ & $0(0 \%)$ \\
\hline Lundh et al. [27] & $\begin{array}{l}\text { METS (Stan- } \\
\text { more Implants } \\
\text { worldwide Ltd, } \\
\text { Stanmore, UK) }\end{array}$ & $\begin{array}{l}\text { Cemented (3), } \\
\text { Cementless (2) }\end{array}$ & N/A & $0(0 \%)$ & $5(100 \%)$ & $0(0 \%)$ & $0(0 \%)$ & $0(0 \%)$ \\
\hline $\begin{array}{l}\text { Grammatopou- } \\
\text { los et al. [28] }\end{array}$ & $\begin{array}{l}\text { METS (Stan- } \\
\text { more Implants } \\
\text { worldwide Ltd, } \\
\text { Stanmore, UK) }\end{array}$ & Cemented & $2.4(0-17)$ & $12(15 \%)$ & $16(20 \%)$ & $6(8 \%)$ & $40(50 \%)$ & $\begin{array}{l}4(5 \%) \text { [Instability } \\
+ \text { pseudotumor] }\end{array}$ \\
\hline Viste et al. [29] & $\begin{array}{l}\text { GMRS (Stryker } \\
\text { Inc., Mahwah, } \\
\text { NJ, US) }\end{array}$ & Cemented & $2(1-10)$ & $0(0 \%)$ & 15 (34\%) & $16(36 \%)$ & $12(27 \%)$ & 1 (2\%) [Instability] \\
\hline
\end{tabular}


Table 2 (continued)

\begin{tabular}{|c|c|c|c|c|c|c|c|c|}
\hline Author (year) & $\begin{array}{l}\text { Type of } \\
\text { implant }\end{array}$ & Fixation & $\begin{array}{l}\text { No. of } \\
\text { previous } \\
\text { surgery } \\
\text { (range) }\end{array}$ & $\begin{array}{l}\text { Primary Fx } \\
\text { (rate) }\end{array}$ & $\begin{array}{l}\text { Periprosthetic } \\
\text { Fx (range) }\end{array}$ & AL (rate) & PJI (rate) & Other \\
\hline $\begin{array}{l}\text { Fenelon et al. } \\
\text { [30] }\end{array}$ & $\begin{array}{l}\text { GMRS (Stryker } \\
\text { Inc., Mahwah, } \\
\text { NJ, US); LPS } \\
\text { (DePuy Synthes, } \\
\text { Warsaw, IN, US) }\end{array}$ & N/A & $1.4(0-10)$ & $2(2.5 \%)$ & $50(63 \%)$ & $9(11 \%)$ & $5(6.3 \%)$ & $\begin{array}{l}13(16.4 \%) \text { [2 } \\
\text { Instability, } 2 \\
\text { Osteoarthritis, } 9 \\
\text { Osteosynthesis } \\
\text { failure] }\end{array}$ \\
\hline $\begin{array}{l}\text { De Martino } \\
\text { et al. [43] }\end{array}$ & $\begin{array}{l}\text { GMRS (Stryker } \\
\text { Inc., Mahwah, } \\
\text { NJ, US) }\end{array}$ & $\begin{array}{l}\text { Cemented (37), } \\
\text { Cementless (4) }\end{array}$ & $3.6(1-11)$ & $0(0 \%)$ & $7(17 \%)$ & $14(34 \%)$ & $17(42 \%)$ & $\begin{array}{l}3(7 \%) \text { [Nonun- } \\
\text { ion] }\end{array}$ \\
\hline $\begin{array}{l}\text { Dieckmann } \\
\text { et al. [32] }\end{array}$ & $\begin{array}{l}\text { MUTARS } \\
\text { (Implantcast } \\
\text { GmbH, Buxte- } \\
\text { hude, DE) }\end{array}$ & Cemented & 2.5 & $0(0 \%)$ & $0(0 \%)$ & $0(0 \%)$ & 49 (100\%) & $0(0 \%)$ \\
\hline Total & - & - & $3.0(0-22)$ & $65(10.3 \%)$ & 187 (29.7\%) & 163 (25.9\%) & $184(29.3 \%)$ & $30(4.8 \%)$ \\
\hline
\end{tabular}

Fx Fracture, N/A Not Available, AL Aseptic Loosening, PJl Periprosthetic Joint Infection

require surgery were $53.7 \%$ ( 22 hips of 41 complications), and DVT was the most frequent with a reported incidence of $1.2 \%$ (7 hips). Further information is outlined in Table 3.

\section{Clinical scores}

Among 18 studies, 10 studies recorded clinical outcomes of PFRs. Six studies reported the preoperative Harris Hip Score (HHS, excellent >90 points, good between 80 to 90 points, fair between 50 to 79 points, and poor $<50$ points) [3, 17, 19, 22, 23, 29], and 8 studies noted the postoperative HHS [3, 17, 19, $22-24,29,32]$. The average postoperative HHS was 72.6 (fair; range, 64.9-83 points). In the 6 studies (213 hips) that have both preoperative and postoperative HHS, improvements were seen on the HHS from mean 35.7 points (poor; range, 30-46 points) preoperatively to mean 72.8 points (fair; range, $65.8-78$ points) at the latest follow up. Two studies (116 hips) reported a mean postoperative Oxford Hip Score (OHS) of 43.7 points (poor; range, $28-54.9$ points) [4, 28]. Two studies $[18,20]$ reported improvements on the Merle d'Aubigné from mean preoperative 4.4 points (range, 3.8-5.1 points) to mean postoperative 14.5 (range, 12.5-16). Al-Taki et al [4] reported a preoperative Western Ontario and McMaster Universities Arthritis Index (WOMAC) of 49.2 (poor) and a postoperative WOMAC mean of 62.2 (good). Toronto Extremity Salvage Score (TESS) was noted postoperatively in two studies $[23,24]$. It is a patient-reported measure of function designed to assess physical disability for patients after limb-salvage surgery for musculoskeletal tumors. Its lower extremity version consists of 30 questions regarding everyday activities such as dressing, working, mobility and leisure and allows a percentage score to be calculated. The mean postoperative score was $69.5 \%$ (range $68-71 \%$ ). Further information on clinical outcomes is outlined in Table 4 .

\section{Discussion}

Our review of the literature suggests that PFR implants are an effective way to manage severe femoral bone loss in non-oncologic primary and revision THA in case of elderly and less active patients with multiple comorbidities where an early mobilization and immediate full weight bearing are crucial for a faster recovery [33]. The all-cause reoperation-free survivorship after PFR implantation was $76.6 \%$ (447 of 578 hips) at a mean follow-up of 4.3 years. The overall complication rate was high at $27.2 \%$ (157 of 578 hips), with dislocation as the most commonly reported (12.8\%), followed by infection $(7.6 \%)$, and implant AL (5.9\%), suggesting that despite acceptable short-to mid-term survivorship given the high complexity of these patients, PFR should be considered as a salvage procedure when other reconstruction options are no longer available. In addition, PFR are currently used in multiple settings, the most common indication was periprosthetic fracture in $29.7 \%$ of the cases (187 hips), followed by PJI in $29.3 \%$ (184 hips), AL in $25.9 \%$ (163 hips), primary comminuted fracture in osteoporotic bone in $10.3 \%$ (65 hips), and other indications in 4.8\% (30 hips).

Among the current alternative surgical options, allograft prosthesis composites (APC) are usually preferred in case of young patients with primary bone tumors and failed THA where an adequate bone stock is required for potential further revisions. While the megaprostheses are associated with early weight bearing and superior early outcomes, allograft-prosthesis composites have shown 


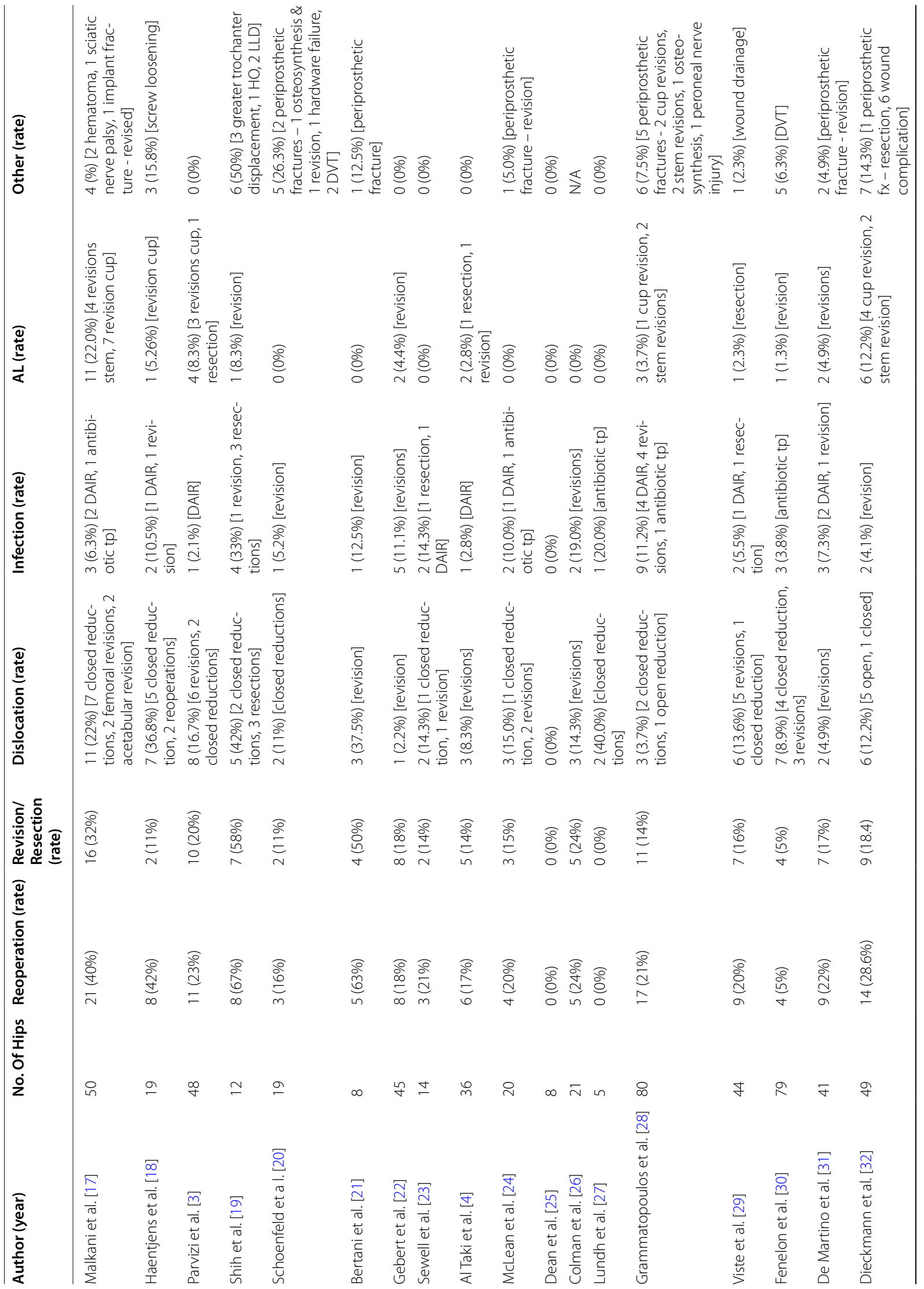




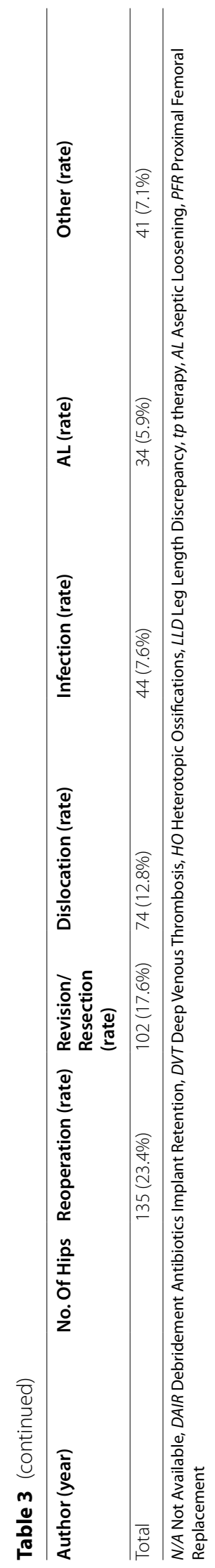


Table 4 Clinical outcomes of proximal femoral replacement implants

\begin{tabular}{|c|c|c|c|}
\hline Author (year) & Preoperative (range) & Postoperative (range) & $P$ (value) \\
\hline Malkani et al. [17] & $\begin{array}{l}\text { HHS } 46 \pm 13(31-83) \\
\text { Mayo Clinic hip score } 30 \pm 17 \text { (11-60) }\end{array}$ & $\begin{array}{l}\text { HHS } 76 \pm 16 \text { (41-94) } \\
\text { Mayo Clinic hip score } 57 \pm 18 \text { (18-75) }\end{array}$ & $\begin{array}{l}<0.01 \\
<0.01\end{array}$ \\
\hline Haentjens et al. [18] & Merle d'Aubigné 5.1 & Merle d'Aubigné 14.9 & N/A \\
\hline Parvizi et al. [3] & HHS 37.1 (15-61) & HHS $64.9(13-91)$ & $<0.05$ \\
\hline Shih et al. [19] & HHS 30 (16.-42) & HHS 83 (68-92) & N/A \\
\hline Schoenfeld et al. [20] & $\begin{array}{l}\text { Primary: Merle d'Aubigné N/A } \\
\text { Revision: Merle d'Aubigné } 3.77\end{array}$ & $\begin{array}{l}\text { Primary: Merle d'Aubigné } 16 \\
\text { Revision: Merle d'Aubigné } 12.5\end{array}$ & N/A \\
\hline Bertani et al. [21] & N/A & MSTS $13.8 \pm 6.8$ & N/A \\
\hline Gebert et al. [22] & HHS 30 (8-63) & HHS 78 (57-95) & N/A \\
\hline Sewell et al. [23] & $\begin{array}{l}\text { HHS } 28(13-49) \\
\text { TESS } 26 \%(14-40)\end{array}$ & $\begin{array}{l}\text { HHS } 69 \text { (39-85) } \\
\text { TESS } 71 \%(35-82)\end{array}$ & $\begin{array}{l}<0.0001 \\
<0.0001\end{array}$ \\
\hline Al Taki et al. [4] & $\begin{array}{l}\text { WOMAC } 49.2 \\
\text { OHS } 34.9 \\
\text { SF-12 physical } 30.8 \\
\text { SF-12 mental } 38.9 \\
\text { UCLA activity } 2.6\end{array}$ & $\begin{array}{l}\text { WOMAC } 62.2 \\
\text { OHS } 54.9 \\
\text { SF-12 physiscal } 37 \\
\text { SF-12 mental } 50.8 \\
\text { UCLA activity } 3.9\end{array}$ & $\begin{array}{l}0.168 \\
0.003 \\
0.220 \\
0.030 \\
0.528\end{array}$ \\
\hline McLean et al. [24] & N/A & $\begin{array}{l}\text { SF-36 physical } 53 \text { (44-62) } \\
\text { SF-36 mental } 51 \text { (41-64) } \\
\text { TESS } 68 \text { (32-98) }\end{array}$ & N/A \\
\hline Dean et al. [25] & N/A & HHS 71.4 (64-85) & N/A \\
\hline Colman et al. [26] & N/A & N/A & N/A \\
\hline Lundh et al. [27] & N/A & N/A & $\mathrm{N} / \mathrm{A}$ \\
\hline Grammatopoulos et al. [28] & N/A & OHS 28 (4-48) & N/A \\
\hline Viste et al. [29] & HHS 42.8 $\pm 20(25.9-82.9)$ & HHS 65.8 $\pm 15.6(21-87.7)$ & 0.0009 \\
\hline Fenelon et al. [30] & N/A & N/A & N/A \\
\hline De Martino et al. [31] & N/A & N/A & N/A \\
\hline Dieckmann et al. [32] & $\mathrm{N} / \mathrm{A}$ & HHS 69 (40-94) & N/A \\
\hline
\end{tabular}

MSTS Musculo-Skeletal Tumor Society score, TESS Toronto Extremity Salvage Score, HHS Harris Hip Score, N/A Not Available, OHS Oxford Hip Score, UCLA University of California at Los Angeles, WOMAC Western Ontario and McMaster Universities, N/A Not Available

improved functional outcome and implant survivorship at long-term follow-up. In addition, they allow the reattachment of the gluteus and iliopsoas tendons supporting hip biomechanics and increasing postoperative hip stability. However, infection, non-union, allograft resorption, periprosthetic fracture and risk of disease transmission continue to be major issues, and the final outcome is strictly related on the etiology, soft tissue damage, type of bone defect, method of reconstruction, and preparation of the allograft $[12,13]$.

Despite the effectiveness of PFR in restoring function, overall complications rate is high. Hip dislocation was the most frequent complication with an overall prevalence of $12.8 \%$ ( 74 of 578 hips), higher than the one usually seen after revision THA with conventional implants at shortto-midterm follow-up [34]. Among those, the 59.5\% required subsequent reoperation (44 hips), whilst $40.5 \%$ were treated nonoperatively (30 closed reductions). In case of reoperation for recurrent dislocation, the majority $(81.8 \%)$ required a full revision or resection arthroplasty, suggesting the complex management after dislocation in these kinds of patients. However, if excluding the studies that used monobloc and custom-made implants and considering only the ones that implanted modular PFR implants $[3,4,20-32]$ the overall dislocation rate was $10.3 \%$ (51 of 497 hips), suggesting that modularity enables the surgeon to restore better offset, limb length and soft-tissue tension, providing better postoperative stability compared to older monobloc implants. In addition, our results showed a slightly reduced dislocation rate compared with the rates reported by Vaishya et al [35] that noted a dislocation rate of $14.6 \%$ (out of 245 PFRs) at a mean 44 months follow-up in a critical analysis of proximal and distal femoral replacement, and by Korim et al [33] that noted a dislocation rate of $15.7 \%$ (out of 356 PFRs) at mean 45 months follow-up in non-oncologic conditions, suggesting that newer implants may provide increased stability. In fact, if we consider only the recent literature (after 2010) [4, 22-32], the dislocation rate results considerably reduced compared to the previous studies probably related not only to the modular systems but also to the increased usage of constrained acetabular liners and dual mobility cups [36-39]. Recurrent dislocation is multifactorial and commonly related to multiple 
previous procedure and inadequate soft tissue envelop with abductor mechanism deficiency, especially of the posterior vertical fibers of the gluteus medius are considered the main actor in providing dynamic hip stability $[40,41]$. In addition, most of the patients included are relatively old with multiple comorbidities that can increase the risk of dislocation [42-44]. Modular implants present a porous-coated proximal surface that promotes osseointegration with the possibility to approximate the retained proximal host bone to the implant enhancing implant's stability [3]. Moreover, a possible solution to reduce the dislocation rate in case of abductor deficiency was proposed by Du et al. [45]. The authors used a band-shaped artificial ligament wrapped spirally around the proximal site of the total femur prosthesis for periacetabular soft tissue reconstruction in a cohort of 48 PFRs implanted for neoplastic reasons and reported a reduced dislocation rate [46].

Infection was the second most frequent complication reported in $7.6 \%$ of the cases ( 44 of 578 hips), in line with what have been previously reported [32, 34, 47]. Among those, further surgery was required in $84.1 \%$ of the cases (37 of 44 infections), while conservative treatment with suppressive antibiotic therapy was reported in $15.9 \%$ of the cases (7 of 44 infections). Among the PJIs that underwent subsequent surgery, 14 of them were DAIR (37.8\%) and 23 of them were either 2-stage revision to a total femur replacement or resection arthroplasty (62.2\%). PJI remains the most challenging complication after PFR because of poor quality soft tissue, poor overall health, and long operative times [24, 48, 49]. Currently, surface coating with iodine and silver [50] have shown a reduced infection rate, improving implant retention and reducing amputations in case of PJI, however, these implants were not clearly used in all the studies included and it was not possible to stratify the infection rate regarding this characteristic [32, 51, 52].

Aseptic loosening of the implant was reported with an incidence of $5.9 \%$ ( 34 of 578 hips), comparing favorably with what has been previously reported [35]. All cases of AL required subsequent reoperation, revision of the cup was performed in $47.1 \%$ of the cases (16 hips), followed by revision of the femoral component in $23.4 \%$ (8 hips), revision of both components in $20.5 \%$ (7 hips), and resection arthroplasty in $8.8 \%$ (3 hips).

Despite a relatively high level of complications for current treatment option, patients receiving a PFR showed considerable improvement in a variety of functional scores. Specifically, it was associated with an average of a 42.5 HHS increase between preoperative and postoperative periods. On average, patient improved from "poor" health (mean preoperative HHS of 35.7) to "fair" health (mean postoperative HHS of 72.8) at latest follow-up.
These results suggest that PFR remain an efficacious procedure, improving patient functionality and outcomes, especially in complex patients with severe proximal femoral bone loss.

There were a variety of limitations in this study. First, we were limited by the quality of the original studies, the variability in inclusion criteria as well as the methods for reporting the evaluated variables, and number of patients analyzed. Second, our methodology did not allow for identification of unpublished literature on PFR and is limited by potential publication bias. Several different outcome scores were used across the included studies to assess overall hip function. The studies included were heterogeneous, including small sample sizes and different implant used. The studies covered a large time period reflecting the use of variable implant designs from original monobloc to new modular implants. Limited information available on the complications in each cohort did not allow to stratify for indication and provide a better overview on which indication of PFR is associated with better/worse outcomes.

\section{Conclusion}

To date, given the designs available and the current literature, PFR should be considered a valuable option in case of salvage procedure in complex patients affected by severe proximal femoral bone loss when other available reconstruction options cannot be utilized. Newer designs have shown improved stability and clinical outcomes; however, dislocation and infection remain major issues after PFR, and long-term survivorship has not been clearly defined. In conclusion, PFR should be considered as a limb salvage option in carefully selected patients when other options are not feasible.

\section{Abbreviations}

PFR: Proximal femoral replacement; THA: Total hip arthroplasty; PJI: Periprosthetic joint infection; AL: Aseptic loosening; HHS: Harris Hip Score; WOMAC: Western Ontario and McMaster Universities; TESS: Toronto Extremity Salvage Score; OHS: Oxford Hip Score; APC: Allograft Prosthesis Composites; DVT: Deep Vein Thrombosis; DAIR: Debridement Antibiotics and Implant Retention.

\section{Acknowledgements \\ Not applicable}

\section{About this supplement}

This article has been published as part of BMC Musculoskeletal Disorders Volume 22 Supplement 2 2021: All about the hip. The full contents of the supplement are available at https://bmcmusculoskeletdisord.biomedcentral.com/ articles/supplements/volume-22-supplement-2.

\section{Authors' contributions}

FMa, IDM: designing the work. FMa, VDM, FMo, GC, CP, GM: acquisition and analysis of the data. FMa: drafting the work. IDM: revised it critically for important intellectual content. All authors have read and approved the final version of the manuscript. 


\section{Funding}

This research did not receive any specific grant from funding agencies in the public, commercial, or not-for-profit sectors. Publication costs are founded by Division of Orthopaedics and Traumatology, Department of Aging, Neurological, Orthopaedic and Head-Neck studies, Fondazione Policlinico Universitario Agostino Gemelli IRCCS, 00168 Rome, Italy.

\section{Availability of data and materials}

All data generated or analyzed during this study are included in this published article. The datasets used and/or analyzed during the current study are available from the corresponding author on reasonable request.

\section{Declarations}

\section{Ethics approval and consent to participate}

Not applicable

\section{Consent for publication}

Not applicable

\section{Competing interests}

The authors have no conflicts of interest to declare that are relevant to the content of this article. No benefits in any form have been received or will be received from a commercial party related directly or indirectly to the subject of this article.

\section{Author details}

${ }^{1}$ Division of Orthopaedics and Traumatology, Department of Aging, Neurological, Orthopaedic and Head-Neck studies, Fondazione Policlinico Universitario Agostino Gemelli IRCCS, 00168 Rome, Italy. ${ }^{2}$ Catholic University of the Sacred Heart, Largo Francesco Vito 1, 00168 Rome, Italy. ${ }^{3}$ Adult Reconstruction and Joint Replacement Service, Division of Orthopaedics and Traumatology, Department of Aging, Neurological, Orthopaedic and Head-Neck studies, Fondazione Policlinico, Universitario Agostino Gemelli IRCCS, Largo Agostino Gemelli 8, 00168 Roma, RM, Italy. ${ }^{4}$ Orthopaedic Institute of Southern Italy "Franco Scalabrino", Messina, Italy.

Received: 12 September 2021 Accepted: 14 September 2021 Published online: 08 November 2021

\section{References}

1. Malahias M-A, Mancino F, Gu A, Adriani M, De Martino I, Boettner F, et al. Acetabular impaction grafting with mesh for acetabular bone defects: a systematic review. Hip Int. 2020. https://doi.org/10.1177/1120700020 971851.

2. Parvizi J, Sim FH. Proximal femoral replacements with megaprostheses. Clin Orthop Relat Res. 2004;420:169-75. https://doi.org/10.1097/00003 086-200403000-00023.

3. Parvizi J, Tarity TD, Slenker N, Wade F, Trappler R, Hozack WJ, et al. Proximal femoral replacement in patients with non-neoplastic conditions. J Bone Joint Surg Am. 2007;89(5):1036-43. https://doi.org/10.2106/JBJS.F.00241.

4. Al-Taki MM, Masri BA, Duncan CP, Garbuz DS. Quality of life following proximal femoral replacement using a modular system in revision THA. Clin Orthop Relat Res. 2011;469(2):470-5. https://doi.org/10.1007/ s11999-010-1522-2.

5. Springer BD, Berry DJ, Lewallen DG. Treatment of periprosthetic femoral fractures following total hip arthroplasty with femoral component revision. J Bone Joint Surg Am. 2003;85(11):2156-62. https://doi.org/10.2106/ 00004623-200311000-00015.

6. Friesecke C, Plutat J, Block A. Revision arthroplasty with use of a total femur prosthesis. J Bone Joint Surg Am. 2005;87(12):2693-701. https:// doi.org/10.2106/JBJS.D.02770.

7. Meluzio MC, Oliva MS, Minutillo F, Ziranu A, Saccomanno MF, Maccauro G. The use of knee mega-prosthesis for the management of distal femoral fractures: A systematic review. Injury. 2020;51(Suppl 3):S17-22. https:// doi.org/10.1016/j.injury.2019.08.011.

8. Mancino F, Cacciola G, Di Matteo V, De Marco D, Greenberg A, Malahias MA, et al. Reconstruction options and outcomes for acetabular bone loss in revision hip arthroplasty. Orthop Rev (Pavia). 2020a;12(Suppl 1):8655. https://doi.org/10.4081/or.2020.8655.

9. Oliva MS, Vitiello R, Cauteruccio M, Pesare E, Rovere G, Meschini C, et al. Cemented versus cementless megaprosthesis in proximal femur metastatic disease: A systematic review. Orthop Rev (Pavia). 2020;12(Suppl 1):8689. https://doi.org/10.4081/or.2020.8689.

10. Gosheger G, Gebert C, Ahrens H, Streitbuerger A, Winkelmann W, Hardes J. Endoprosthetic reconstruction in 250 patients with sarcoma. Clin Orthop Relat Res. 2006;450:164-71. https://doi.org/10.1097/01.blo.00002 23978.36831.39.

11. Menendez LR, AhImann ER, Kermani C, Gotha H. Endoprosthetic reconstruction for neoplasms of the proximal femur. Clin Orthop Relat Res. 2006:450:46-51. https://doi.org/10.1097/01.blo.0000229332.91158.05.

12. Min L, Peng J, Duan H, Zhang W, Zhou Y, Tu C. Uncemented allograftprosthetic composite reconstruction of the proximal femur. Indian J Orthop. 2014;48(3):289-95. https://doi.org/10.4103/0019-5413.132521.

13. Gautam D, Malhotra R. Megaprosthesis versus Allograft Prosthesis Composite for massive skeletal defects. J Clin Orthop Trauma. 2018;9(1):63-80. https://doi.org/10.1016/j.jcot.2017.09.010.

14. Mancino F, Cacciola G, Di Matteo V, Perna A, Proietti L, Greenberg A, et al. Surgical implications of the hip-spine relationship in total hip arthroplasty. Orthop Rev (Pavia). 2020b;12(Suppl 1):8656. https://doi.org/10. 4081/or.2020.8656

15. Moher D, Liberati A, Tetzlaff J, Altman DG, PRISMA Group. Preferred reporting items for systematic reviews and meta-analyses: the PRISMA statement. Ann Intern Med. 2009;151:264e9.

16. OCEBM Levels of Evidence Working Group*."The Oxford levels of evidence 2". Oxford Centre for Evidence-Based Medicine. https://www. cebm.net/index.aspx? 05653 (Accessed 1 Mar 2021).

17. Malkani AL, Settecerri JJ, Sim FH, Chao EY, Wallrichs SL. Long-term results of proximal femoral replacement for non-neoplastic disorders. J Bone Joint Surg Br. 1995;77(3):351-6.

18. Haentjens P, De Boeck H, Opdecam P. Proximal femoral replacement prosthesis for salvage of failed hip arthroplasty: complications in a 2-11 year follow-up study in 19 elderly patients. Acta Orthop Scand. 1996;67(1):3742. https://doi.org/10.3109/17453679608995606.

19. Shih ST, Wang JW, Hsu CC. Proximal femoral megaprosthesis for failed total hip arthroplasty. Chang Gung Med J. 2007;30(1):73-80.

20. Schoenfeld AJ, Leeson MC, Vrabec GA, Scaglione J, Stonestreet MJ. Outcomes of modular proximal femoral replacement in the treatment of complex proximal femoral fractures: a case series. Int J Surg. 2008;6(2):140-6. https://doi.org/10.1016/j.ijsu.2008.01.009.

21. Bertani A, Helix M, Louis ML, Rochwerger A, Curvale G. Total hip arthroplasty in severe segmental femoral bone loss situations: use of a reconstruction modular stem design (JVC IX). Retrospective study of 23 cases. Orthop Traumatol Surg Res. 2009;95(7):491-7. https://doi.org/10.1016/j. otsr.2009.07.011.

22. Gebert C, Wessling M, Götze C, Gosheger G, Hardes J. The Modular Universal Tumour And Revision System (MUTARS ${ }^{\circledR}$ ) in endoprosthetic revision surgery. Int Orthop. 2010;34(8):1261-5. https://doi.org/10.1007/ s00264-010-1007-7.

23. Sewell MD, Hanna SA, Carrington RW, Pollock RC, Skinner JA, Cannon SR, et al. Modular proximal femoral replacement in salvage hip surgery for non-neoplastic conditions. Acta Orthop Belg. 2010;76(4):493-502.

24. McLean AL, Patton JT, Moran M. Femoral replacement for salvage of periprosthetic fracture around a total hip replacement. Injury. 2012;43(7):1166-9. https://doi.org/10.1016/j.injury.2012.03.024.

25. Dean BJ, Matthews JJ, Price A, Stubbs D, Whitwell D, Gibbons CM. Modular endoprosthetic replacement for failed internal fixation of the proximal femur following trauma. Int Orthop. 2012;36(4):731-4. https://doi.org/10. 1007/s00264-011-1332-5.

26. Colman M, Choi L, Chen A, Crossett L, Tarkin I, McGough R. Proximal femoral replacement in the management of acute periprosthetic fractures of the hip: a competing risks survival analysis. J Arthroplasty. 2014;29(2):422-7. https://doi.org/10.1016/j.arth.2013.06.009.

27. Lundh F, Sayed-Noor AS, Brosjö O, Bauer H. Megaprosthetic reconstruction for periprosthetic or highly comminuted fractures of the hip and knee. Eur J Orthop Surg Traumatol. 2014;24(4):553-7. https://doi.org/10. 1007/s00590-013-1237-7.

28. Grammatopoulos G, Alvand A, Martin H, Whitwell D, Taylor A, Gibbons CL. Five-year outcome of proximal femoral endoprosthetic arthroplasty for 
non-tumour indications. Bone Joint J. 2016;98-B(11):1463-70. https://doi. org/10.1302/0301-620X.98B11.BJJ-2016-0244.R1.

29. Viste A, Perry KI, Taunton MJ, Hanssen AD, Abdel MP. Proximal femoral replacement in contemporary revision total hip arthroplasty for severe femoral bone loss: a review of outcomes. Bone Joint J. 2017;99-B(3):3259. https://doi.org/10.1302/0301-620X.99B3.BJJ-2016-0822.R1.

30. Fenelon C, Murphy EP, Kearns SR, Curtin W, Murphy CG. Cemented proximal femoral replacement for the management of non-neoplastic conditions: a versatile implant but not without its risks. J Arthroplasty. 2020;35(2):520-7. https://doi.org/10.1016/j.arth.2019.09.010.

31. De Martino I, D'Apolito R, Nocon AA, Sculco TP, Sculco PK, Bostrom MP. Proximal femoral replacement in non-oncologic patients undergoing revision total hip arthroplasty. Int Orthop. 2019a;43(10):2227-33. https:// doi.org/10.1007/s00264-018-4220-4.

32. Dieckmann R, Schmidt-Braekling T, Gosheger G, Theil C, Hardes J, Moellenbeck B. Two stage revision with a proximal femur replacement. BMC Musculoskelet Disord. 2019;20(1):58. https://doi.org/10.1186/ s12891-019-2442-2.

33. Korim MT, Esler CN, Ashford RU. Systematic review of proximal femoral arthroplasty for non-neoplastic conditions. J Arthroplasty. 2014;29(11):2117-21. https://doi.org/10.1016/j.arth.2014.06.012.

34. Kosashvili Y, Backstein D, Safir O, Lakstein D, Gross AE. Dislocation and infection after revision total hip arthroplasty: comparison between the first and multiply revised total hip arthroplasty. J Arthroplasty. 2011;26(8):1170-5. https://doi.org/10.1016/j.arth.2011.04.022.

35. Vaishya R, Thapa SS, Vaish A. Non-neoplastic indications and outcomes of the proximal and distal femur megaprosthesis: a critical review. Knee Surg Relat Res. 2020;32(1):18. https://doi.org/10.1 186/s43019-020-00034-7.

36. De Martino I, D'Apolito R, Soranoglou VG, Poultsides LA, Sculco PK, Sculco TP. Dislocation following total hip arthroplasty using dual mobility acetabular components: a systematic review. Bone Joint J. 2017a;99B(ASuppl1):18-24. https://doi.org/10.1302/0301-620X.99B1.BJJ-20160398.R1 Erratum in: Bone Joint J. 2017;99-B(5):702-704.

37. De Martino I, D'Apolito R, Waddell BS, McLawhorn AS, Sculco PK, Sculco TP. Early intraprosthetic dislocation in dual-mobility implants: a systematic review. Arthroplast Today. 2017b;3(3):197-202. https://doi.org/10.1016/j. artd.2016.12.002.

38. Waddell BS, De Martino I, Sculco T, Sculco P. Total hip arthroplasty dislocations are more complex than they appear: a case report of intraprosthetic dislocation of an anatomic dual-mobility implant after closed reduction. Ochsner J. 2016;16(2):185-90.

39. Addona JL, Gu A, De Martino I, Malahias MA, Sculco TP, Sculco PK. High rate of early intraprosthetic dislocations of dual mobility implants: a single surgeon series of primary and revision total hip replacements. J Arthroplasty. 2019;34(11):2793-8. https://doi.org/10.1016/j.arth.2019.06. 003.

40. Jones SA. Constrained acetabular liners. J Arthroplasty. 2018;33(5):1331-6. https://doi.org/10.1016/j.arth.2018.01.026.

41. Mancino F, Jones CW, Sculco TP, Sculco PK, Maccauro G, De Martino I. Survivorship and clinical outcomes of constrained acetabular liners in primary and revision total hip arthroplasty: a systematic review. J Arthroplasty. 2021;36(8):3028-41. https://doi.org/10.1016/j.arth.2021.04.028.

42. Jones CW, De Martino I, D'Apolito R, Nocon AA, Sculco PK, Sculco TP. The use of dual-mobility bearings in patients at high risk of dislocation. Bone Joint J. 2019;101-B(1_Supple_A):41-5. https://doi.org/10.1302/0301620X.101B1.BJJ-2018-0506.R1.

43. De Martino I, Strigelli V, Cacciola G, Gu A, Bostrom MP, Sculco PK. Survivorship and clinical outcomes of custom triflange acetabular components in revision total hip arthroplasty: a systematic review. J Arthroplasty. 2019b;34(10):2511-8. https://doi.org/10.1016/j.arth.2019.05.032.

44. De Martino I, De Santis V, D'Apolito R, Sculco PK, Cross MB, Gasparini G. The Synergy cementless femoral stem in primary total hip arthroplasty at a minimum follow-up of 15 years. Bone Joint J. 2017c;99-B(1):29-36. https://doi.org/10.1302/0301-620X.99B1.BJJ-2016-0231.R1.

45. Du Z, Tang S, Yang R, Tang X, Ji T, Guo W. Use of an artificial ligament decreases hip dislocation and improves limb function after total femoral prosthetic replacement following femoral tumor resection. J Arthroplasty. 2018;33:1507-14. https://doi.org/10.1016/j.arth.2017.12.017.

46. D’Adamio S, Cazzato G, Ziranu A, Sgambato A, Rosa MA, Maccauro G. Soft tissue adhesion patterns over Trevira tube on modular endoprosthesis for malignant bone tumours: an in vitro study. J Biol Regul Homeost Agents. 2017;31(4 suppl 1):37-42.

47. De Gori M, Scoccianti G, Frenos F, Bettini L, Familiari F, Gasparini G, et al. Modular endoprostheses for nonneoplastic conditions: midterm complications and survival. Biomed Res Int. 2016;2016:2606521. https://doi.org/ 10.1155/2016/2606521.

48. Lamagni T. Epidemiology and burden of prosthetic joint infections. J Antimicrob Chemother. 2014;69(Suppl 1):i5-10. https://doi.org/10.1093/ jac/dku247.

49. Piccioli A, Donati F, Giacomo GD, Ziranu A, Careri S, Spinelli MS, et al. Infective complications in tumour endoprostheses implanted after pathological fracture of the limbs. Injury. 2016;47(Suppl 4):S22-8. https:// doi.org/10.1016/j.injury.2016.07.054.

50. Donati F, Di Giacomo G, D’Adamio S, Ziranu A, Careri S, Rosa M, et al. Silver-coated hip megaprosthesis in oncological limb savage surgery. Biomed Res Int. 2016;2016:9079041. https://doi.org/10.1155/2016/90790 41.

51. Tsuchiya $H$, Shirai T, Nishida H, Murakami H, Kabata T, Yamamoto $\mathrm{N}$, et al. Innovative antimicrobial coating of titanium implants with iodine. J Orthop Sci. 2012;17(5):595-604. https://doi.org/10.1007/ s00776-012-0247-3.

52. Hardes J, von Eiff C, Streitbuerger A, Balke M, Budny T, Henrichs MP, et al. Reduction of periprosthetic infection with silver-coated megaprostheses in patients with bone sarcoma. J Surg Oncol. 2010;101(5):389-95. https:// doi.org/10.1002/jso.21498.

\section{Publisher's Note}

Springer Nature remains neutral with regard to jurisdictional claims in published maps and institutional affiliations.
Ready to submit your research? Choose BMC and benefit from:

- fast, convenient online submission

- thorough peer review by experienced researchers in your field

- rapid publication on acceptance

- support for research data, including large and complex data types

- gold Open Access which fosters wider collaboration and increased citations

- maximum visibility for your research: over $100 \mathrm{M}$ website views per year

At BMC, research is always in progress.

Learn more biomedcentral.com/submissions 